Research Article

\title{
Remuneration as a tool for increasing Employee Performance in Nigerian
}

\author{
Onyekwelu, R.U $U^{1}$, Dike, E.E. $E^{2}$ Muogbo, U.S $S^{3}$ \\ ${ }^{1,2,3}$ Department of Public Administration, Chukwuemeka Odumegwu Ojukwu University, Nigeria
}

\begin{abstract}
This research work assesses fundamentally remuneration as a device for expanding employee performance with specific reference to Bottling Companies in Nigeria. The broad aim of this research is to decide the role of remuneration in expanding workers performance. The population of the study is 200. The study adopt primary and secondary sources to gather information and copies of questionnaire were used also. The research adopted survey and descriptive research technique in analyzing data acquired from Bottling Companies in Nigeria while hypotheses was tested using Regression analysis and ANOVA. It was found that remuneration assumes a significant role in increasing workers performance in an organisation. The study therefore suggests that organisation ought to embrace the right remuneration tool that meets the craving of their workers so as to increase their output.
\end{abstract}

Key works: Remuneration, Salary, Rewards, Indirect compensation, employee productivity, workers satisfaction

\section{Introduction}

The idea of remuneration goes back to $2150 \mathrm{BC}$ when Sunierian social orders have actualized the main laws to repay workers for real bodily injuries. With time, the idea has bit by bit gained its contemporary significance, and has transformed into a conceivable and successful instrument of remunerating laborers and shielding businesses from harm suits. Remuneration is regarded as the benefits the workers receive which can come in form wages, rewards, and pay for the worker's to increase the productivity (Holt, 1993). Pay is very necessary for lifestyles because employee gets rewards from the employer for the work he did. In human resources management, the essential obligation is remuneration management. Remuneration is a complex task that takes place intermittently. There is need for employee integration, tactics and information with organization's process and strategies in order to achieve organisational desires and goals. Truly, remuneration management is a serious device to "incorporate individual efforts with strategic firm's goals through inspiring employees to do the right things with ever attractive efficiency. Remuneration send clean messages to all workers of the organisation notifying them about anticipated attitudes and behaviors (Schell and Solomon, 2007).

Davis et al (2003) noticed that the idea of "remuneration" was changing as per the changing states of work. Remuneration is genuinely viewed as the most antiquated type of social protection. Industrialization and the development of the new types of work required adjusting the fundamental compensatory arrangements to the need of the working society "Simply defined, workers' remuneration recompenses, offers something to a worker who performs work for another, for services rendered for injuries (Hood, Hardy Lewis, 2004). Verifiably, even the antiquated social orders practiced different sets of rules which later took for the type of remuneration. It is believed that remuneration is the "glue" which ties the workers and the employer jointly in a firm, this is additionally classified as an agreement or a legal document that mutually binds both the worker and employer that spells out precisely the amount ought to be paid to the worker and component of the remuneration package. Although, Maslow's Hierarchy Theory discusses remuneration as the center to bring down step of the pyramid and the 
other elements like job contentment and fulfilment being at the top, for most of the employees, getting the exact remuneration is by its self an encouraging factor. Accordingly, businesses need to evaluate worker's commitment in a suitable way if they want the employee to bring out their best. In every organisation, the provision of monetary reward in exchange for work performance forms the basis of remuneration and how this is managed using process, procedures, and frameworks form the basis of remuneration management. (Reeve, 2004). Subsequently, in light of the above background, this study intends to find out the role of remuneration in increasing employee performance and retention with particular reference to Nigerian bottling companies.

\section{Problem Statement}

The study and comprehension of human conduct has sit for a strong challenge to both the researchers and professionals. They have been keen on discovering the reasons for human behaviour. The behavioural scientists need to discover why individuals behave the manner in which they do. Scientific management school of thought accept that many individual are spurred mainly by financial rewards and lay emphasis on the part of remuneration and other monetary rewards for increase in performance. Behavioural method guarantee conducive environment and increases financial benefit were not adequate sparks for growing productivity. There is an ongoing argument among researchers if man is completely a "Social man" or an "Economic man" (Chandan, 2005). Reward levels is exceptional amongst most vital components recruiters think about while choosing their employees and the total amount of remuneration gotten by the workers with respect to different chances they may have, has an effect on retention. Pay significantly affects workers attitude, performance and efficiency in organizations. Retention of capable workers are becoming a headache in some firms. Diverse procedures might be designed to do a similar thing like enhancing the working condition, good employee-management relationship, attracting remuneration framework, promotion opportunities; and so on. Despite its being one of the most basic factor for which an individual join an organisation less attention has been given to examining organisational members' evaluations of various remuneration and benefits packages. A need exists to analyze the employees' perceptions of the remuneration and benefit policy of their organisation and how workers differ in their perceptions. Considering the perspective of scientific management, the problem of the study was what will be the view of workers towards the remuneration and benefit package in their organisation.

\section{Objectives of the Study}

The broad aim of this research is to assess the role of remuneration in increasing employee productivity, specifically the objectives include:

1. To determine if there is an effect of wages on employee performance.

2. To examine the degree at which incentives affects job satisfaction.

3. To ascertain the level at which indirect rewards affects workers rate of turnover in business organization

\section{Research Questions}

Below are the research questions:

1. Is there any correlation between wages and employee productivity?

2. At what degree can effective incentives affects job satisfaction?

3. At what level can indirect remuneration affects the rate of workers turnover in a firm?

\section{Statement of Hypotheses}

To answer the research questions above the following hypotheses were formulated in a null form.

H01: There is no correlation between wages and employee productivity,

H02: Effective incentives cannot affect job satisfaction among employees.

H03: Indirect reward cannot affect the rate of workers turnover in an organization.

\section{Review of Related Literature}

So as to carry out effective study on remuneration as a tool for increasing employee performance, the relevant literatures were reviewed underneath.

\section{Concept of Remuneration}


Remuneration is about the satisfaction that workers gets for the work done which includes all forms of payment or rewards and adding to the satisfaction, moreover this support the organisation to acquire, keep up and hold a beneficial workforce. It is believed that remuneration is the "stick" that ties the workers and the business together and in the cooperate organisation, this is furthermore classified as an contract which is legally binding and spells out specifically what sum should be paid to the employee and the components of the remuneration package. Generally, motivation as a procedure is an internal interest of the individuals and this is the motivation of the conduct of the person who will aim to address this issue. This stream is described by Reeve (2004), Davis and Newstrom (2003). The progression of motivation is dynamic and individual, these have diverse components for instance physiological, psychological and social and these collaborate between theirs. Applying the model of Davis and Newstrom (2003), the remuneration is the prize gotten by explicit behaviors.

\section{Incentives and Rewards:}

Reward is very important for employee productivity. Employees feels the worth of their organisation if their well-being is considered first. Employee becomes the device of the organizational expansion and can accomplish organisational intentions if their career selfevaluation is considered too. Mark and ford (2001) posit that organisational success from employee is the preparedness to use their inventiveness and increase the positive inputs and obtain their rewards duly. It is important to motivate the employee duly especially if the employee is highly productive, effectively contributing and eager to perform their obligations in the organizations. Hurtreatal 1990; Entwested 1987 observed that when employee performance is effective more than their employers, employers rewards them in accordance with their performance. Employees assist their organisation to achieve its objectives and build advantages for their company when they are highly motivated (Rizal and Ali, 2010). Hasiban 2003 specified that the level of employee performance increases if they feel satisfied with their job which means that satisfaction derived from rewards thus makes the workers feel so good. The most vital instrument used to inspire employee for putting their best energies to generate the creativity and the new ideas for the firm performance whether financial or non-financial is reward. Dee prose (2014) posit that employee increases their productivity if they are motivated. The capability of the organization to accommodate the needs of employees towards effective job performance lies on good rewards.

\section{Indirect Compensation}

As per (Dessler, 2011) Indirect Compensation is the indirect financial and non-money related remuneration workers get for continuing on with their assignment with the business enterprise, this is a basic component of employee's pay. Different vocabularies utilized for indirect pay are fringe benefits, workers administrations, advantageous remuneration and beneficial compensation. According to (Chhabra, 2001), Indirect or Supplementary remuneration comprises of 'fringe advantages' rendered through various workers services and advantages like housing, financial help for nourishment, medical allowance, childcare places for children's, etc. In the organisation rewards are given by managers to workers for their enrollment, participation or cooperation. Due to the consistent increment in the expenses of fringe benefits, a few people used the term 'shrouded finance' for them .Presently these advantages comprise around $40 \%$ of the entire remuneration charges for every worker of the organisation. The essential objective of fringe benefits or indirect remuneration is to attract, energize and retain competent HR in the organisation.

\section{Empirical Review}

Remuneration Theories largely accepted that advanced performance includes more noteworthy exertion or that it is some other way related with disutility with respect to workers. In order to stimulate, these theories anticipate the presence of remuneration systems that structure compensation so that employee's normal utility grows with observed profitability. These rewards can take a wide range of structures, including commendation from superior and subordinates, implicit assurances of future promotion opportunities, feelings of sureness that begin from predominant achievement and acknowledgment, and present and future money rewards related to performance. 
Abdul, Muhammad, Ramzan, Hafiz, and Zubair, (2014) studied on Impact of Compensation on Employee Performance in Pakistani Banking Sector. The goal of their research was to gauge the effect of remuneration on worker performance. Questionnaire were designed to gather information on the variables identified with pay like salary, rewards, Indirect Compensation and employee performance. The information gathered were analyzed in SPSS 17.0 Version. Distinctive analytical and expressive systems were used to analyze the information. Their findings disclose that Compensation has positive effect on worker performance. It was proved from the connection investigation that all the independent variables have frail or moderate positive relationship to one another. Both descriptive analysis, ANOVA results and regression analysis shows that all the independent variables have immaterial and positive effect on worker performance. This work gives bits of knowledge to the supervisors to improve the employee performance.

Onuorah, Okeke, and Ibekwe (2019) studied on Compensation Management and Employee Performance in Nigeria. The study was underpinned on Human Capital Theory and Expectancy Theory. With descriptive survey design, 257 public secondary schools students were selected as the population. In investigating the information for the null hypotheses, Z-test was used at 0.05 level of significance. The investigation discovered that value based pay, competency based pay and performance based pay has no negative impact on employee performance in Nigeria organisation. The research along these lines presume that compensation management has an essentialness impact on employee performance in Nigeria firms. It was recommends that each organisation should make value based remuneration as mandatory arrangement since value based pay are used more broadly in firms for guaranteeing most extreme performance.

Osibanjo, Adeniji, Falola, and Heirsmac (2014) examined Compensation packages: a key tool for workers' performance and retention. The aim of their investigation was to look at the impact of remuneration packages on workers' job performance and retention in a chosen private Universities in Ogun State, South-West Nigeria.
They built up a model and tried it using one hundred and eleven questionnaire which were completed by teaching and non-teaching staff of the college. The information gathered were painstakingly analyzed using simple percentage supported by structural equation modelling to test the hypotheses and connections that may exist among the variables under consideration. The outcomes indicated solid connection between pay packages and workers' performance and retention. The findings demonstrates that there is solid connection between the tested dependent and independent variables (compensation, bonus, motivators, allowances, and fringe benefits). Nonetheless, the management and decision makers should attempt to review compensation packages at different levels so as to gain workers' fulfillment and avoidance of high work turnover among the members of staff.

\section{Research Methodology}

This research examined role of remuneration on employee performance in Nigeria. The study tries to know the correlation of variables like wages, incentive, and indirect compensation on worker's output. 210 Questionnaire were shared amongst the selected staff of the Nigerian bottling company. In order to measure the effect of reward, salary, compensation and employee performance, five Likert scale of Strongly Disagree (1), Disagree (2), Undecided (3), Agree (4), Strongly Agree (5) were applied. Out of 210 questionnaire distributed, two hundred were properly filled and returned while five were missing and five was invalid. Mean, frequencies and standard deviation were applied for the descriptive analysis. Correlation and regression were used to measure the effect and correlation among the dependent and independent variables.

\section{Results and Discussion \\ Table 1: Correlation analysis}

\begin{tabular}{|l|l|l|l|l|l|}
\hline \multicolumn{2}{|c|}{} & \multirow{2}{|c|}{$\begin{array}{l}\text { Sala } \\
\text { ry }\end{array}$} & $\begin{array}{l}\text { Rewa } \\
\text { rds }\end{array}$ & $\begin{array}{l}\text { Indirect } \\
\text { Compensa } \\
\text { tion }\end{array}$ & $\begin{array}{l}\text { Perform } \\
\text { ance }\end{array}$ \\
\hline Wages & $\begin{array}{l}\text { Pearson } \\
\text { Correlatio } \\
\mathrm{n}\end{array}$ & & $.498^{* *}$ & $.270^{* *}$ & .070 \\
\cline { 3 - 6 } & $\begin{array}{l}\text { Sig. } \\
\text { tailed) } \\
\mathrm{N}\end{array}$ & & .000 & .000 & .312 \\
\cline { 3 - 6 } & & 200 & 200 & 200 \\
\hline
\end{tabular}


Onyekwelu, R.U et. al/ Remuneration as a tool for increasing Employee Performance in Nigerian

\begin{tabular}{|c|c|c|c|}
\hline \multirow{3}{*}{$\begin{array}{l}\text { Incenti } \\
\text { ve }\end{array}$} & \multirow{3}{*}{$\begin{array}{l}\text { Pearson } \\
\text { Correlatio } \\
\mathrm{n} \\
\text { Sig. (2- } \\
\text { tailed) } \\
\mathrm{N}\end{array}$} & $.268 * *$ & -047 \\
\hline & & .000 & .501 \\
\hline & & 200 & 202 \\
\hline \multirow{3}{*}{$\begin{array}{l}\text { Indirect } \\
\text { reward }\end{array}$} & \multirow{3}{*}{$\begin{array}{l}\text { Pearson } \\
\text { Correlatio } \\
\mathrm{n} \\
\text { Sig. (2- } \\
\text { tailed) } \\
\mathrm{N}\end{array}$} & & .093 \\
\hline & & & .182 \\
\hline & & & 200 \\
\hline \multicolumn{4}{|c|}{ **. Correlation is significant at the 0.01 level (2-tailed). } \\
\hline
\end{tabular}

\section{Source: Field Survey 2019}

Table 1 shows the analysis of the correlation of variables wages, incentives, indirect reward and employee performance. The relationship of these variables is summarized above and the table indicates positive relationship amongst the variables. From the table, the variable shows that increase in one affects the other positively and can as well increase employee performance.

Table 2: Regression Analysis

\begin{tabular}{|c|c|c|c|c|c|c|}
\hline & & & & & & \\
\hline & del & $\begin{array}{l}\text { Unsta } \\
\text { Coeff }\end{array}$ & dized & $\begin{array}{l}\text { Standa } \\
\text { Coeffic }\end{array}$ & $\mathrm{t}$ & Sig \\
\hline & & B & $\begin{array}{l}\text { Std. } \\
\text { error }\end{array}$ & Beta & & \\
\hline 1 & (Constant) & 3.658 & .314 & & $\begin{array}{l}11.5 \\
77\end{array}$ & .000 \\
\hline & wages & 0.95 & .072 & $8^{.10}$ & $\begin{array}{l}1.31 \\
6\end{array}$ & .188 \\
\hline & incentives & -.080 & .053 & -.127 & $\begin{array}{l}- \\
1.56 \\
5\end{array}$ & .118 \\
\hline & $\begin{array}{l}\text { Indirect } \\
\text { reward }\end{array}$ & .083 & .062 & $0^{.10}$ & $\begin{array}{l}1.35 \\
0\end{array}$ & .177 \\
\hline
\end{tabular}

\section{Source: Field Survey 2019}

Table two shows the effect of wages, incentives and indirect reward on employee performance. The value of chronbach's alpha is 0.05 . Below is the impact of these variables:

Wages: H01: There is no correlation between wages and employee performance. The table indicates the significance value for the variable wages is 0.188 which is greater than alpha but the value of $B$ is minor which means that there may be other factors as well. However the result shows insignificance therefore alternate hypotheses is rejected and assume that workers' wages has positive impact on performance of the workers.

Incentives: H02. Effective incentive cannot affect job satisfaction among employee. The value of incentive is greater than alpha (0.119>.05) therefore the results are insignificant and hence the null hypothesis is accepted. Accordingly, from the regression results the study conclude that incentive has positive effect on employee performance.

\section{Regression Equation}

Employee Performance $=3.658+0.095$ Salary 0.080 Rewards + 0.083 Indirect compensation

\section{Table 3: Descriptive Analysis}

\begin{tabular}{|c|c|c|c|}
\hline \multicolumn{3}{|l|}{ Statistics } & \multirow{2}{*}{$\begin{array}{l}\text { Descriptive } \\
\text { Std. Deviation }\end{array}$} \\
\hline & $\mathbf{N}$ & Mean & \\
\hline wages & 200 & 4.0867 & .37394 \\
\hline incentives & 200 & 4.0706 & .52604 \\
\hline $\begin{array}{l}\text { Indirect } \\
\text { rewards }\end{array}$ & 200 & 4.0924 & .38842 \\
\hline Performance & 200 & 4.0702 & .32977 \\
\hline $\begin{array}{l}\text { Valid N (list } \\
\text { wise) }\end{array}$ & 200 & & \\
\hline
\end{tabular}

\section{Source: Authors computation 2019}

The analysis of wages, incentives, indirect rewards and employee performance are in agreement in descriptive analysis which means that all the variables will increase employee performance. From the standard deviation result the variation in data of wages is 3.70-4.45. The mean results lies between the range and it indicates that the respondents are all in agreement that wages has positive effect on employee performance. It therefore concludes that rewards has positive impact on employee performance. Moreover, it is very clear that the values of 
indirect compensation lies between the ranges of strongly agree and agree from the standard deviation result which means that these variables have also positive effect on employee performance.

\section{ANOVA Analysis}

Educational Level

Table 4: wages

\begin{tabular}{|c|c|c|c|c|c|}
\hline & & & & & JOVA \\
\hline wages & & & & & \\
\hline & $\begin{array}{l}\quad \text { Sum } \\
\text { of } \\
\text { Square } \\
\text { s }\end{array}$ & $\mathrm{df}$ & Mean Square & $\mathrm{F}$ & Sig. \\
\hline $\begin{array}{l}\text { Betwee } \\
\text { n } \\
\text { Groups }\end{array}$ & 1.011 & 3 & $\begin{array}{ll} & .33 \\
6 & \end{array}$ & $\begin{array}{l}2.56 \\
4\end{array}$ & $8^{.05}$ \\
\hline $\begin{array}{l}\text { Within } \\
\text { Groups }\end{array}$ & 20.471 & $\begin{array}{l}15 \\
5\end{array}$ & $\begin{array}{ll} & .13 \\
2 & \end{array}$ & & \\
\hline Total & 21.481 & $\begin{array}{l}15 \\
8\end{array}$ & & & \\
\hline
\end{tabular}

The table 4 shows that the value 0.0581 is greater than the value of alpha 0.05 which means that the result is significance. It indicates that wages has positive impact on employee performance.

\section{Summary of Findings, Conclusion And Recommendations Summary of Findings}

From the study examined clearly remuneration assume an essential role in employee performance. In accordance with the view of Jack Welch that "If you pick the right individuals and offer them the opportunity to spread their wings - and put remuneration and rewards as a carrier behind it you almost don't have to manage them." It is perceived that remuneration is the "stick" that binds the workers and the employers firmly in a firm, this is regarded as bargain or a mutually binding legal document that writes out specifically the amount to be paid to the workers and the types of the reward package. Consequently, every organisation must consider remuneration management important if actually they want to achieve a competitive advantage in the market.

\section{Conclusion}

From the data gathered and all the results obtained from the analysis, it is concluded that remuneration (wages, incentives, indirect rewards) plays positive impact on employee performance. This is clear from the descriptive and correlation analysis that all variables (independent) have positive relationship to each other. Remuneration is very important in human resources management of every organisation because it has great impact on productivity, growth and development of an organisation. Presently, most of the corporate organisation have considered it essential to fuse viable remuneration mechanism for their employees as part of their organisational goals. This will enable the workforce have a strategic performance goals and accomplish them. Conclusively, remuneration should not be neglected in an organisation because it attracts, retain and spur workers for enhanced organisational productivity.

\section{Recommendations}

From the study, well-planned and great remuneration mechanism plays an important part in providing organized human resource management processes which can be supportive to enhancing organisational viability. Accordingly, organisational board should adequately design, formulate and objectify remuneration strategy so as to improve the achievement of overall organisational objectives with a view of getting the best contribution from employees.

Based on the findings, it is recommended that:

$>$ There should be adequate remuneration mix that suits the needs of employees of every organisation so as to get the best from them.

$>$ Rewards, wages, remuneration and direct incentives should be harnessed in the overall compensation package.

$>$ Every organisation should endeavor to know what appeals most to their workers to enable them know the correct compensation for their employees.

\section{References}


1. Adewale, O, O., Adenike, A. A., Hezekiah O F. \& Heirsmac, P. T. (2014). Compensation packages: a strategic tool for employees' performance and retention. Leonard Journal of Science. 25 65- 84

2. Akter, N. \& Moazzam, H. (2016). Effect of compensation on job performance: An empirical study. International Journal of Engineering Technology, Management and Applied Science. 4, (8),

3. Ahmed, J.U. (2013). Human Resources Management practices in readymade garments industry of Bangladesh. University of Chittagong, Bangladesh.

4. Alnaqbi, W. (2011). The relationship between human resource practices and employee retention in public organisations: an exploratory study conducted in the United Arab Emirates. (Unpublished PhD thesis, Edith Cowan University, Australia.

5. Arnolds, C. A., \& Boshoff, C. (2002). Compensation, esteem valence and job performance: an empirical assessment of Alderfer's ERG theory. International Journal of Human Resource Management, 13(4), 697-719.

6. Begbie, C., Bussin, M. \& Schurink, W. (2011). A food-manufacturing manager's experiences and perceptions of the implementation of an incentive scheme', $\boldsymbol{S A}$ Journal of Human Resource Management, 9, 1-13.

7. Carr, J. \& Hasan, M. (2008). An Empirical Study of Performance Measurement Systems in Manufacturing Companies', Journal of Achievements in Materials and Manufacturing Engineering, 31, 616-621.

8. Chile. Davis K. \& Newstrom J. (2003). Human behaviour at work. 8th Edition. Los Angeles: McGraw-Hill.

9. Dessler, G. (2011). Fundamentals of human resource management. Pearson Higher Ed.

10. Danish, R.Q., \& Usman, A. (2010). Impact of Reward and Recognition on Job Satisfaction and Motivation: An Empirical Study from Pakistan', International Journal of Business and Management, 5, 159-167.

11. Edralin, D.M. (2010). Human Resource Management Practices: Drivers for Stimulating Corporate Entrepreneurship in Large Companies in the Philippines', DLSU
Business \& Economics Review, 19, 25-41.

12. Erdogan, B. (2002). Antecedents and Consequences of Justice Perceptions in Performance Appraisals', Human Resource Management Review, 12, 555-578.

13. Euske, K., Lebas, M.J. \& McNair, C. (1993). Performance Management in an International Setting', Management Accounting Research, 4, 275-299.

14. Evans, J.R. (2004). An Exploratory Study of Performance Measurement Systems and Relationships with Performance Results', Journal of Operations Management, 22, 219-232.

15. Falola H. O., Ibidunni A. S, Olokundun A. M., Incentives packages and employees' attitudes to work: a study of selected government parastatals in Ogun State, South-West, Nigeria, International Journal of Research in Business and Social Science IJRBS, 2014, 3(1), p. 2147-4478.

16. Fernondez I. (2002). Trends in Management Compensation in the Chilean Market, XVIII Inter-American Congress of Psychology". Access on 6 April 201: www.ignaciofernandez.cl

17. Flanner, T. Hofrichter, D. \& Flatten, P. (2007). People, Performance and Payment: Dynamic Compensation for the New Business Environment". Paidos Editorial.

18. Galanou, E., Sotiropoulos, I. Georgakopoulos, G. \& Vasilopoulos, D. (2011). The Effect of Reward System on Job Satisfaction in an Organizational Chart of Four Hierarchical Levels: A Qualitative Study', International Journal of Human Sciences, 8,485-520.

19. Gerhart, B., \& Milkovich, G.T. (1990). Organizational Differences in Managerial Compensation and Financial Performance', The Academy of Management Journal,33, 663-691.

20. Ghazi, S.R., Ali, R., Shahzada, G. and Israr, M. (2010). University Teachers' Job Satisfaction in the North West Frontier Province of Pakistan, Asian Social Science, 6, 188-192.

21. Gruman, J.A. \& Saks, A. M. (2011). Performance Management and Employee Engagement, Human Resource Management Review, 21, 123-136.

22. Huselid, M.A, (1995). The Impact of 
Human Resource Management Practices on Turnover, Productivity, and Corporate Financial Performance, the Academy of Management Journal, 38, 635-672.

23. Jian, Z., Xiao, Q., Qi, H. \& Xiao, L. (2009). Total Reward Strategy: A Human Resources Management Strategy Going with the Trend of the Times' International Journal of Business and Management, 4, 177-183.

24. Jo, S.; Kong, L., Hussin, Z.H. \& Jusoff, K. (2008). The Influence of Employee Benefits Towards Organizational Commitment', Asian Social Science, 4,147-150.

25. Kirn. H., Sutton, K.L. \& Gong, Y. (2011). Group-based Pay-for-performance Plans and Firm Performance: The Moderating Role of Empowerment Practices' Asia Pacific Journal of Management, 1-22.

26. Kohn, A. (2008). Incentives Can Be Bad for Business. INC (January): 93-94. Lawler, Edward E. III. (2001). Pay and Organizational Effectiveness: A Psychological View. New York: McGraw-Hill.

27. Kwak J. \& Lee, E. (2009). An Empirical Study of "Fringe Benefits" and Performance of the Korean Firms', International Journal of Business and Management, 4, 3-9.

28. Lebas, M.J. (1995). Performance Measurement and Performance Management, International Journal of Production Economics, 41, 23-35.

29. Loana, S.L. \& Raluca, R.N. (2011). General Considerations Regarding the Evaluation of Performances of Employees in a SME', Annals of the University of Oradea: Economic Science, 1,719-722.

30. Luthans, F. \& Stajkovic, A.D. (2009). Reinforce for Performance: The Need to Go beyond Pay and Even Rewards, The Academy of Management Executive, 13, 49-57.

31. Maiya, U., Krishnamurthy, M. \& Sukhesh, P. (2011). Employees' Perception towards Organizational Success through Performance Management System', Indian Journal of Commerce \& Management Studies, 2, 177-184.

32. Medoff, J... \& Abraham, K.G. (2000). Experience, Performance and Earnings. Quarterly Journal of Economics, 95 (December): 703-36.
33. Osibanjo A.O., Abiodun A.J., Fadugba, A.O., Executive perception of the impact of flexitime on organisational performamce: evidence from the Nigeria Private Sector, International Journal of Applied Behavioural Economics, IJABE, 2012, 1(3), p. 16-27. 4. Oshagbemi T., Gender Differences in the job satisfaction of university

34. Osibanjo A.O., Abiodun A.J., Fadugba, A.O. (2012). Executive perception of the impact of flexitime on organisationalperformamce: evidence from the Nigeria Private Sector, International Journal of Applied Behavioural Economics, IJABE, 1(3), 16-27.

35. Qureshi, M O. \& Sajjad, S.R. (2015). An empirical analysis of the impact of compensation on job performance and work-family conflict in the kingdom of Saudi Arabia- a correlation model. European Scientific Journal, 11(4), 18577881.

36. Reeve, J. (1994). Motivation and Emotion. India: McGraw- Hill Robbins, S. (2004). Organizational Behaviour. London: Pearson Editions.

37. Sopiah, (2013). The Effect of Compensation toward Job Satisfaction and Job Performance of Outsourcing Employees of Syariah Banks in Malang Indonesia. International Journal of Learning \& Development, 3(2), 77-91.

38. Villanueva, A. \& Gonzales, E. (2005). "Management of Compensation I" Chile: Press Publishe 